\begin{tabular}{|c|c|c|}
\hline \multirow{2}{*}{ NA } & $\begin{array}{l}\text { Науковий вісник НлТУ України } \\
\text { Scientific Bulletin of UNFU }\end{array}$ & \begin{tabular}{|l|l} 
(c) & ISSN 1994-7836 (print) \\
BY ISSN 2519-2477 (online)
\end{tabular} \\
\hline & https://doi.org/10.15421/40280909 & $@ \bowtie$ Correspondence author \\
\hline & $\begin{array}{l}\text { Article received } 15.10 .2018 \mathrm{p} . \\
\text { Article accepted } 25.10 .2018 \mathrm{p} .\end{array}$ & $\begin{array}{r}\text { M. S. Kaflyk } \\
\text { andruschakevich1994@i.ua }\end{array}$ \\
\hline & УДК 502.[131.1+174.3]:674.8 & \\
\hline
\end{tabular}

М. С. Кафлик

Національний лісотехнічний університет України, м. Львів, Україна

\title{
ЕКОЛОГО-ЕКОНОМІЧНІ ПІДХОДИ ДО ЕНЕРГЕТИЧНОГО ВИКОРИСТАННЯ ДЕРЕВНОЇ БІОМАСИ $З$ ВІДХОДІВ ВИРОБНИЦТВА В УКРАЇНІ
}

\begin{abstract}
Деревинна біомаса є основним джерелом енергії серед відновлюваних джерел в Україні. Питання біоенергетичного використання деревини розглянуто в контексті впровадження у практику ведення лісового господарства на засадах наближеного до природи лісівництва та сталого, невиснажливого використання лісових ресурсів. Проаналізовано основні показники відходів деревної біомаси в Україні. Доведено важливість використання відходів деревної біомаси в контексті сталого розвитку з урахуванням економічної, екологічної та соціальної складових цього процесу. В Україні немає спеціалізованих підприємств, які постачають біомасу компаніям з виробництва біопалива. Деревину постачають безпосередньо державні лісогосподарські підприємства та деревообробні підприємства, які можуть постачати відходи від деревообробки. Лісові вторинні ресурси потрібно використовувати згідно з каскадним принципом - насамперед для виробництва продукції 3 масиву і переробляти повторно для максимального збільшення поглинання і нагромадження вуглецю, а тільки після цього - для виробництва енергії. Актуальним завданням є розвиток комплексних лісогосподарських підприємств, до складу яких входитиме перероблення відходів деревної біомаси в енергетичних цілях. Відходи лісогосподарського та лісопильного виробництва $€$ високим біоенергетичним потенціалом для формування ефективного способу господарювання (економіки) на біоекономічних засадах.
\end{abstract}

Ключові слова: біоенергетичний потенціал; біопаливо; біоенергетична продукція; вторинна сировина; екологічно чистий енергетичний ресурс.

Вступ. Питання заміни невідновлюваних джерел енергії відновлюваними в Україні щороку набуває дедалі більшої вагомості. Актуальною є проблема екологоекономічного обгрунтування управлінських рішень щодо розширеного використання альтернативних джерел теплової енергії, зокрема і деревної. Україна має високий біоенергетичний потенціал, що пояснюють недостатньо використовуваними можливостями залучення відновлюваних природних ресурсів. Значну частину сировини для виготовлення біоенергетичної продукції експортують, а відходи лісосік практично не використовують. Якщо цей обсяг відходів використовувати для отримання біоенергії, виробництва біомаси, іiї перероблення, та виробництва біоенергетичної продукції з вищою доданою вартістю (дрова колоті, пелети, брикети та ін.), це сприятиме покращенню економічної ситуації 3 одночасним збереженням вичерпних природних ресурсів та покращенням соціального добробуту населення.

Аналіз досвіду низки країн (зокрема Швейцарії та Фінляндіi), а також досвіду СС стосовно розроблення i впровадження на національному рівні стратегій біоекономіки засвідчує, що використання відходів деревної біомаси в енергетичних цілях дає змогу вирішити проблему дефіциту енергетичних ресурсів в Україні та зробить внесок у реалізацію концепції сталого розвитку (Safonov, 2012; Wood biomass, 2016).

Аналіз тенденцій розвитку енергетичних ринків зас- відчує, що глобальний попит на енергію швидко зростає. На сьогодні викопне паливо становить понад 80 \% від загального обсягу поставок енергії, однак частка відновних джерел енергії неухильно зростає.

Об'єкти та методика дослідження. Об'єкm дослідження - відходи деревної біомаси, які можна використати в енергетичних цілях. Предмет дослідження - теоретичні основи аналізу стану та ефективності використання відходів деревної біомаси, які можуть бути використані в енергетичних цілях (Wood biomass, 2016; Safety, 2017).

Мета дослідження - обгрунтувати підходи до енергетичного використання відходів деревної біомаси 3 економічної та екологічної точок зору в контексті сталого розвитку.

Результати дослідження. Вторинне використання деревної біомаси набуло поширення в багатьох промислово розвинених країнах, зокрема в країнах ЄС, Японії та США. Як зазначають автори П. Р. Пуцентейло та Н. Б. Свинтух (Putsenteyro \& Svyntuh, 2013), у процесі оброблення деревини, починаючи від лісопиляння, утворюється до $40 \%$ відходів деревини, що містять у своєму складі: хмиз, верхню частину дерева, середню та дрібну частину деревини, зріз, тирсу. Переробка лісосічних відходів може бути ефективним рішенням проблеми дефіциту енергетичних ресурсів в Україні та отримання чималої кількості теплової енергії.

Інформація про авторів:

Кафлик Марія Степанівна, аспірант, кафедра екологічної економіки. Email: andruschakevich1994@i.ua

Цитування за Дсту: Кафлик М. С. Еколого-економічні підходи до енергетичного використання деревної біомаси з відходів виробництва в Україні. Науковий вісник НЛтУ України. Серія Економічна. 2018, т. 28, № 9. С. 49-53

Citation APA: Kaflyk, M. S. (2018). Environmental and economic approaches of wood biomass from residuals usage for energy production. Scientific Bulletin of UNFU, 28(9), 49-53. https://doi.org/10.15421/40280909 
На сьогодні наведені вище відходи переважно спалюють. Зауважимо, що на підприємствах, які сертифіковані за стандартом ведення лісового господарства FSC, від цієї практики відмовляються, оскільки вона не відповідає вимогам стандартів. 3 огляду на це важливим завданням лісогосподарського виробництва є раціональне та ефективне використання відходів лісозаготівлі та деревообробки в енергетичних цілях.

Відходи деревини утворюються на всіх стадіях іiі технологічного циклу, починаючи від лісозаготівлі (неліквідна деревина, верхівки, сучки, пні), в процесі оброблення (відходи розпилу колод, рейки, горбилі, ошурки, стружка) та в процесі подальшої технологічного перероблення, наприклад целюлозно-паперове виробництво. Автори Д. В. Степанов, С. Й. Ткаченко та А. П. Ранський зазначають, що найефективнішими методами перероблення таких деревних відходів $є$ піроліз та газифікація з отриманням водню, горючих газових сумішей та активованого вугілля (Stepanov, Tkachenoko \& Ranskyy, 2012).

Нерозвиненість сектору подальшого перероблення вторинної сировини на підприємствах лісового комплексу пояснюють відсутністю технічного обладнання та збитковістю процесу такої переробки у багатьох випадках через високі логістичні витрати. Це призводить не тільки до несприятливих економічних наслідків втрата екологічно чистої сировини, але і тягне за собою негативний екологічний ефект - забруднення довкілля, що полягає в утворенні великих сміттєзвалищ, спалюванні та рознесенні вітром дрібних частинок відходів. Саме тому раціональне та ефективне використання відходів деревної біомаси дасть змогу вирішити економічну та екологічну складові проблеми утилізації деревних відходів в Україні.

Враховуючи те, що багато деревообробних та целюлозно-паперових підприємств розташовані в межах великих міст та їхніх околиць, де емітується великий обсяг різноманітних відходів, зростає негативний екологічний ефект від їх утилізації, а розташування таких підприємств за містом, або в сільських місцевостях створює проблему з транспортним сполученням, що у багатьох випадках стає економічно недоцільним.

Проекти побудови окремих відходопереробних підприємств деревної біомаси не є інвестиційно привабливими. Автори П. Р. Пуцентейло та Н. Б. Свинтух пропонують модернізувати лісогосподарські і деревообробні підприємства, організувати глибоку хіміко-механічну та лісохімічну переробку вторинної сировини 3 одночасним одержанням малооб'ємної продукції високої вартості та повним використанням на місці низькоякісної сировини (Putsenteyro \& Svyntuh, 2013).

Модернізація сучасних лісогосподарських підприємств та створення комплексних деревообробних комбінатів має включати сектор подальшого перероблення відходів деревної біомаси в енергетичних цілях, безпосередньо на місцях первинної обробки деревини (Putsenteyro \& Svyntuh, 2013; Vis, 2010). Такий спосіб перероблення деревних відходів є оптимальним у сучасних умовах для України. Це дасть змогу лісогосподарським підприємствам отримувати додаткові фінансові надходження від реалізації біоенергетичної продукції, а для населення - можливість отримати якісний екологічно чистий енергетичний ресурс 3 дотриманням законодавства й одночасним збереженням природного довкілля.

Застосування відходів деревної біомаси в енергетичних цілях має грунтуватись на результатах оцінки економічної, екологічної та соціальної складових, що $є$ запорукою реалізації концепції сталого розвитку у лісовому секторі економіки.

Важливим аспектом перероблення відходів деревної біомаси в енергетичний ресурс $є$ ефективність самого процесу, що залежить від кількості, якості та умов формування біоенергетичного потенціалу деревної біомаси.

Визначення напрямку подальшого використання деревних відходів характеризується такими показниками: 1) розмірно-якісні: великі-кускові; дрібні-м'які;

2) економічні: доступність; рентабельність (Putsenteyro, \& Svyntuh, 2013)

Найціннішим видом відходів деревної біомаси вважають кускові відходи. Вони утворюються протягом цілого процесу оброблення деревини, починаючи від лісозаготівлі. Найбільша їх кількість досягається на стадії лісопилення. Вони становлять від 8 до 30 \% від цілого обсягу перероблюваної деревини. До кускових відходів належать: горбиль, рейки, вирізки, обрізки. Саме кускові відходи вважають найціннішою вторинною сировиною. На закордонних підприємства, зокрема у Швейцарії, більшість вторинної продукції виготовляють саме 3 кускових відходів. Основними видами такої продукції є штахетник, тара, конструкційні матеріали (Putsenteyro \& Svyntuh, 2013). В Україні кускові відходи використовують лише частково. Здебільшого на деревообробних підприємствах 3 них виготовляють піддони, що мають найбільший попит на українському ринку.

На рис. 1 подано види біоенергетичного потенціалу деревної маси за походженням.

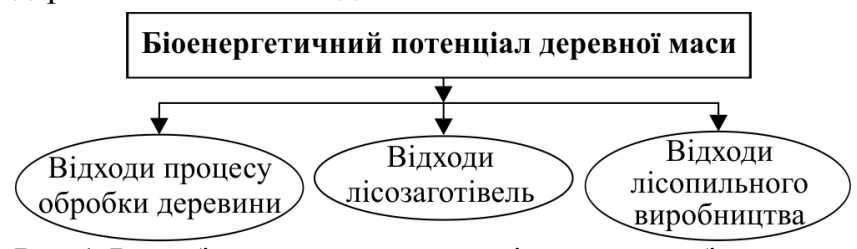

Рис. 1. Види біоенергетичного потенціалу деревної біомаси за походженням

На основі аналізу європейського досвіду (Vis, 2010) можна зробити висновок, що збільшення обсягу використання деревних відходів дає змогу збільшити приріст товарної продукції без зростання обсягів лісогосподарського виробництва.

Дрібні-м'які відходи є менш популярними та бажаними, ніж кускові. Здебільшого їх використовують як наповнювач, або паливо. Вид м'яких деревних відходів залежить від породного складу деревини, iї якості та устатковання, на якому їх обробляють. Найпоширенішими їх видами є тирса, стружка, деревний пил. Велика кількість тирси утворюється під час лісопильного виробництва та оброблення деревини, а також у меблевому та плитовому виробництві. Стружка та деревний пил існують на деревообробних та меблевих підприємствах.

Набувають поширення такі інноваційні напрямки використання відходів деревини (Putsenteyro \& Svyntuh, 2013):

- отримання енергії кондиційної якості із забруднених промислових відходів деревини (наприклад відпрацьованих дерев'яних шпал, які є небезпечним відходом 3-го класу);

- отримання різних видів рідкого палива. 
Майже $90 \%$ світового виробництва біодизельного палива припадає на країни СС. Там для того, щоб забезпечити швидкі темпи виробництва біопалива і зробити його конкурентоспроможним (порівняно 3 виробництвом бензину і звичайним дизельним паливом), надається державна підтримка у вигляді високих протекціоністських тарифів на нього, масштабних державних субсидій, що виплачуються виробникам біопалива, а також встановленні високих тарифів на імпорт етанолу. Лише активна державна підтримка виробництва екологічно чистого рідкого біопалива робить економічно вигідним цей вид бізнесу (Putsenteyro \& Svyntuh, 2013). В Україні такі технології не використовують через відсутністю законодавчо-нормативної бази, яка регулювала б такий вид діяльності.

Упродовж останніх років інтенсивно всихають смерекові ліси, уражені шкідниками та хворобами в Україських Карпатах, які є найбільшим лісоресурсним потенціалом України (Carpathian, 2017). За даними Агентства сталого розвитку "Форза", в деяких лісгоспах Карпатського регіону смерекові культури становлять від 45 до $77 \%$ усіх лісових угідь. Негативна тенденція спостерігається із ялиною. Близько $35 \%$ ялинових деревостанів пошкоджені кореневою гниллю. Це призводить до втрати високоякісної деревини, внаслідок чого збільшується частка деревної біомаси, яка може бути використана в енергетичних цілях. Тому існують істотні резерви збільшення біоенергетичного потенціалу деревної маси в Україні.

Як показує досвід Швейцарії та Фінляндії, з відходів деревної біомаси можна отримати не лише енергетичні ресурси, але й рідке паливо та хімічні речовини, які є продукцією з високою доданою вартістю.

Основним видом деревних відходів є кускові. 3 них виготовляють технологічні тріску. Її якість, безпосередньо, залежить від якості самої сировини. Здебільшого технологічну тріску застосовують як паливо. Окрім цього, з кускових відходів виготовляють деревну тару та піддони.

В Україні основним видом відходів деревної біомаси, яка має подальше застосування, є тирса. Ї̈і використовують як паливо, а також у целюлозно-паперовій, хутряній, будівельній промисловості, сільському господарстві, а також для виробництва деревного борошна.

У хутряній промисловості використовують тирсу берези та інших твердолистяних порід для чищення верхнього одягу. У будівельній промисловості тирсу використовують як окремо, так із клейовими матеріалами. У сільському господарстві тирса використовують домашні господарства для добавки у добрива та як підстилку для корів.

Окрім наведених вище способів використання відходів деревної біомаси, важливе місце посідає виготовлення 3 твердих кускових відходів енергетичної продукції: деревне вугілля, брикети, брикетовані деревні відходи. В Україні ринок твердого біопалива розвинений, але ще потребує вдосконалення.

Найбільшими виробниками деревного вугілля та брикет в Україні є ТДВ "Переченський лісохімічний комбінат", TOB BioEkoPellet, компанія BioFPeB, Грифсканд-Свалява, ТзОВ ECO TRADE WEST та ФОП Назаров Ecodgy.

Виготовлення деревного вугілля $є$ одним 3 найкращих способів переробки деревної біомаси. У процесі його виробництва використовують не лише відходи від лісозаготівлі, але й утилізується викидна м'яколистяна деревина (Putsenteyro \& Svyntuh, 2013).

Брикети - це сукупність дрібних решток, склеєних між собою деревною смолою, продуктами нафтопереробки або іншими зв'язівними речовинами, що сукупно становить єдину цілу одиницю продукції (брикет). Брикети належать до високоякісних енергетичних ресурсів i мають високий попит як на вітчизняному, так і на закордонному ринках.

Брикетовані деревні відходи - це брикети, але не склеєні між собою. Виготовляються $з$ дрібних деревних решток та відходів і використовуються винятково для опалення домашніх печей та малих заводських установ. Тепловіддача згоряння деревних брикет є більшою, ніж тепловіддача окремих одиниць дров.

Кускові відходи деревної маси є екологічно чистим паливом, оскільки не містять сірки, яка під час згоряння потрапляє в атмосферу і забруднює іiі, а попіл, який залишається після згоряння деревини, є калійним добривом, яке використовують у сільському господарстві для удобрення грунту.

Усі вищенаведені енергопродукти та види деревних відходів отримані внаслідок лісозаготівлі та первинної обробки деревини. Тому вони $є$ екологічно чистими, тобто такими, що не містять шкідливих речовин.

Деревину на деревообробних та меблевих підприємствах переробляють трьома способами: хімічна переробка деревини; механічна переробка деревини; хіміко-механічна переробка деревини.

Під час подальшого оброблення деревини на деревообробних та меблевих підприємствах утворюються особливо небезпечні токсичні відходи. Найнебезпечніші відходи утворюються внаслідок хімічної переробки. Відходи виробництва меблів та інших деревних конструкцій містять клей, лак, плівки у частці від 5 до $25 \%$. Отже, використання вживаної деревини вимагає насамперед іï сортування, що пов'язано 3 додатковими матеріальними витратами. Саме тому в умовах української економіки ця група потенційних деревних ресурсів залишається невикористаною. I лише запровадження відповідного законодавства у сфері використання відходів дало б змогу ширше залучити їх у технологічні процеси, що в умовах малолісної та лісодефіцитної України має вагоме еколого-економічне значення (Forestry, 2017). Ця частина деревних відходів може бути перероблена та використана після ретельного сортування, методика якого давно поширена і використовується в країнах СС.

На рис. 2 зображено структуру відходів деревної біомаси, яка може бути використана в енергетичних цілях в лісозаготівельному виробництві (Formation, 2008).

Під час вивезення лісопродукції крона, зазвичай, залишається у лісі. Частина іï залишків там перегниває, а частина нагромаджується на вантажних пунктах. Саме тому відходи, придатні для виготовлення технологічної тріски, становлять лише 4 \% від об'єму стовбурної частини дерева. Технологічні процеси й устатковання для виробництва технологічної тріски безпосередньо на лісосіці було розроблено достатньо давно. Тому єдиним фактором, який сповільнює темпи використання цієї групи відходів, є високі витрати на їх збирання, сортування, перевезення і зберігання (Formation, 2008). 


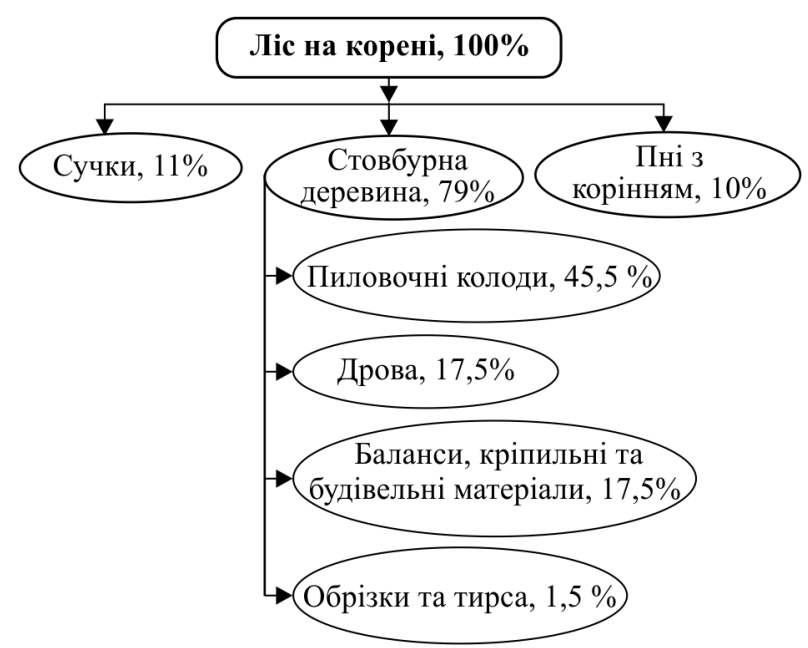

Рис. 2. Структура відходів деревної біомаси лісозаготівельного виробництва, яка може бути використана в енергетичних цілях (на основі джерела (Formation, 2008))

У сучасних умовах на території наявний і доступний обсяг відходів деревної біомаси в Україні можна використовувати в таких напрямках:

- для виробництва будівельних конструкцій;

- для виробництва конструкційних волокнистих матеріалів;

- у біоконсервації;

- для виготовлення паливних брикетів;

- для виготовлення паливних деревних гранул.

В умовах малолісної та лісодефіцитної України ресурси цієї потенційної сировини є досить вагомими, а їх залучення у господарський обіг має важливе економічне, екологічне і соціальне значення.

Висновки. Деревинна біомаса $є$ основним джерелом енергії серед відновлюваних джерел. Ї̈̈ питома вага становить понад 50 \%. Зважаючи на зменшення обсягу використання викопного палива, значно зросте роль деревної маси у сфері використання енергоресурсів.

Стратегією реформування лісового господарства (2017) передбачено важливість впровадження засад наближеного до природи лісівництва та невиснажливого управління лісовими ресурсами для майбутнього розвитку лісів. Ця стратегія базується на засадах екологічної ефективності використання лісових ресурсів, до складу якої входить і використання деревини на біоекономічних засадах.
Україна має значний біоенергетичний потенціал. Врахування соціально-екологічних обмежень під час визначення обсягу біомаси, яка може бути вилучена 3 лісового насадження, забезпечення еколого-економічного обгрунтування всього процесу збирання, сортування та перероблення відходів деревної біомаси є важливим компонентом досягнення концепції сталого розвитку лісового сектору економіки.

\section{Перелік використаних джерел}

Carpathian. (2017). An overview of the use of wood biomass in the Carpathian region of Ukraine. Forza Forza, 18, 123-132. [In Ukrainian].

Forestry. (2017). Strategy of reforming forestry of Ukraine for the period till 2022. Order of the Cabinet of Ministers of Ukraine. Retrieved

from: https://drive.google.com/file/d/0B9CGEXC5v0a9bFZ3ZU9lT0Ixaz g/view. [In Ukrainian].

Formation. (2008). Features of the formation, processing and utilization of wood waste. Retrieved from: https://www.derevo.info/ru/content/detail/. [In Ukrainian].

Putsenteyro, P. G., \& Svyntuh, N. B. (2013). Ecological and economic aspects of the use of wood waste. Ukrainian scientific-industrial magazine. Retrieved from: http://dspace.tneu.edu.ua/handle/316497/10331. [In Ukrainian].

Safety. (2017). Energy Strategy of Ukraine for the period up to 2035 "Safety, Energy Efficiency, Competitiveness". Order of the Cabinet of Ministers of Ukraine dated August 18, No. 605-p, Kiev. Retrieved from: https://de.com.ua/uploads/0/1703-EnergyStratagy2030.pdf. [In Ukrainian].

Safonov, A. O. (2012). Trends in the development of production of composite materials from wood waste. Scientific Journal of the Kuban State University of Agriculture, 75(01). [In Russian].

Stepanov, D. V., Tkachenoko, S. Y., \& Ranskyy, A. P. (2012). Assessment opportunities enerhonrsiyiv organic waste with regard tehnohonnoho load on the environment. Proceedings NTB. Retrieved from: http://stepanov.vk.vntu.edu.ua/file/6bf8155a72bb2acd00ff7357dfe7a998.pdf. [In Ukrainian].

Vis, Martijn. (2010). Harmonization of biomass resource assessments. Vol. I: Best practices and methods handbook. Report on WP5 of the EC FP7 Project Biomass Energy Europe. BTC Biomass Technology Group, B. V., the Netherlands. Retrieved from: http://www.eubee.com. [In english).

Wood biomass. (2016). An overview of the use of wood biomass in the Carpathian region of Ukraine. Results of the SECURECHAIN project within the framework of the EU Horizon 2020 program. NGO "FORZA", 18 p. [In Ukrainian].

М. С. Кафлык

Национальный лесотехнический университет Украины, г. Львов, Украина

\section{ЭКОЛОГО-ЭКОНОМИЧЕСКИЕ ПОДХОДЫ К ЭНЕРГЕТИЧЕСКОМУ ИСПОЛЬЗОВАНИЮ ПРОИЗВОДСТВЕННЫХ ОТХОДОВ ДРЕВЕСНОЙ БИОМАССЫ В УКРАИНЕ}

Древесинная биомасса является основным источником энергии среди восстанавливаемых источников в Украине. Лесные вторичные ресурсы должны использоваться согласно каскадного принципа - в первую очередь для производства продукции из массива и перерабатываться повторно для максимального увеличения поглощения и накопления углерода, а только позже - для производства энергии. Вопрос биоэнергетического использования древесины рассмотрен в контексте внедрения в практику ведения лесного хозяйства на принципах приближенного к природе лесоводства и постоянного, неизнурительного использования лесных ресурсов. Проанализированы основные показатели отходов древесной биомассы в Украине. Доказана важность использования отходов древесной биомассы в контексте устойчивого развития, учитывая экономическую, экологическую и социальную составляющие этого процесса. В Украине отсутствуют специализированные предприятия, которые поставляют биомассу компаниям по производству биотоплива. Древесину поставляют непосредственно государственные лесохозяйственные предприятия и деревообрабатывающие предприятия, которые могут поставлять отходы от деревообработки. Отходы лесного и лесопильного производства являются высоким биоэнергетическим потенциалом для формирования эффективного способа хозяйствования (экономики) на биоэкономических началах.

Ключевые слова: биоэнергетический потенциал; биотопливо; биоэнергетическая продукция; вторичное сырье; экологически чистый энергетический ресурс. 
M. S. Kaflyk

Ukrainian National Forestry University, Lviv, Ukraine

ENVIRONMENTAL AND ECONOMIC APPROACHES OF WOOD BIOMASS FROM RESIDUALS USAGE FOR ENERGY PRODUCTION

Wood biomass is the main source of energy among renewable sources in Ukraine. The issues of wood residuals use for bioenergy purposes are considered in the context of close to nature forestry practices implementation and sustainable management of forest resources. The main indicators of wood biomass use in Ukraine are analyzed. The authors have proved the importance of using wood biomass residuals both from timber harvesting and wood processing in the context of sustainable forest management principles taking into account the economic, ecological and social components of this process. In Ukraine, there are no specialized enterprises supplying biomass to companies producing biofuels. Fuel wood is supplied directly by state forestry enterprises, and wood processing enterprises that can supply wood processing residual. Wood resources and residuals of wood processing industry, in particular, should be used in accordance with the cascade principle - primarily for the production of multiple goods with the highest added value and recycled to maximize the carbon absorption and accumulation, and only later for energy production. The urgent task is to develop integrated forestry enterprises, which will include the wood biomass use for energy purpose into the whole production cycle. Consideration of social and environmental constraints in determining the amount of biomass that can be removed from forest, providing ecological and economic substantiation of the whole process of collecting, sorting and processing wood biomass is an important component of achieving the concept of sustainable forest sector development. Forestry and lumber waste has a high bioenergy potential and, consequently, the formation of an efficient management method (economy) on a bioeconomic basis. The use of wood pulp for energy purposes is extremely eco-efficient, since it involves the replacement of non-renewable natural resources with renewable and minimizes the level of pollution of the environment. In order to stimulate the use of wood waste as an energy resource, market mechanisms are necessary to intensify cooperation between producers of solid biofuels and forestry enterprises.

Keywords: bioenergy potential; biofuel; bioenergy products; secondary raw material; environmentally sound energy resource. 